\title{
New Left Encounters with Marx
}

\author{
Novos encontros da esquerda com Marx
}

\begin{abstract}
The article uses the ideal of a New Left to conceptualize the underlying unity of diverse political experiences during the past half century. Although Marx is not the direct object of this reconstruction, his specter is a recurring presence at those "nodal points" where the imperative to move to "another element" becomes apparent. These are moments when the spirit that has animated a movement can advance no further; it is faced with new obstacles, which may be self-created. The article analyzes from a participant's perspective the development of the New Left in the U.S., France and West Germany as it tried to articulate what is dubbed the "unknown dimension" of Marx's theoretical project.
\end{abstract}

Key Words: Marxism; New Left; Socialism

Resumo: O artigo parte do ideal de uma Nova Esquerda para conceituar a unidade subjacente a diversas experiências políticas durante o último meio século. Embora Marx não seja o objeto direto dessa reconstrução, seu espectro é uma presença recorrente naqueles "pontos nodais", onde o imperativo de se mudar para "outro elemento" torna-se aparente. Estes são os momentos em que o espírito que animou um movimento não pode avançar mais, sendo confrontado com novos obstáculos, que podem ser auto-criados. $\mathrm{O}$ artigo analisa, do ponto de vista de um participante, o desenvolvimento da Nova Esquerda nos EUA, França e Alemanha Ocidental, enquanto tentava articular o que é denominado de "dimensão desconhecida" do projeto teórico de Marx.

Palavras-chave: marxismo; nova esquerda; socialismo

In the mid-196os, as the Cold War seemed frozen into place, the spirit of a "new left" began to emerge in the West. Although encouraged by events in the Third World, its common denominator was the idea that the misunderstood (or misused) work of Karl Marx offered a theory that both explained discontent with the present while offering a guide for future action. At once critical and political, this expectation was encouraged by publications of the writings of the young Marx as well as those of non-orthodox theorists and political activists whose work had

\footnotetext{
${ }^{1}$ Distinguished Professor Emeritus at Stony Brook University. rhoward999@gmail.com
} 
been suppressed by Soviet dominated communist parties. These theories represented an "unknown dimension" ${ }^{2}$ that was the object of vigorous debates in the 196os; but they proved incapable of sustaining the New Left.

Meanwhile, the "old mole" of revolution, as Marx liked to put it, had moved to the East where the multi-faceted movement of civil society against the repressive state brought about fall of communism. Here too, the critical spirit was too weak, economic needs weighed too heavy, and the spirit of utopia waxed. As in the 1960s, Marx can suggest a reason to persevere. In a Preliminary Note to his Dissertation, he justified his refusal to compromise with existing conditions by invoking the example of Themistocles who, "when Athens was threatened with devastation, convinced the Athenians to take to the sea in order to found a new Athens on another element." 3 This is not an anticipation of Marx's turn to political economy. Like the New Left, Marx was trying to articulate the critique of a present "beneath contempt" which holds open a political future.

I will use this ideal of a New Left to conceptualize the underlying unity of diverse political experiences during the past half century. Although Marx is not the direct object of my reconstruction, his specter is a recurring presence at those "nodal points" where the imperative to move to "another element" becomes apparent. These are moments when the spirit that has animated a movement can advance no further; it is faced with new obstacles, which may be self-created. I will analyze from a participant's perspective the development of the New Left in the U.S., France and West Germany as it tried to articulate what I call the "unknown dimension" of Marx's theoretical project.

\section{Innocent Beginnings}

As the Civil Rights movement spread, and still more as it merged with protests against the anti-Vietnam war, it was necessary to propose a political theory to explain both the conditions against which protest was raised, and the future projects and goals of the movement. This two-sided

\footnotetext{
${ }^{2}$ C.f. the collection of essays that Karl E. Klare and I co-edited, The Unknown Dimension. European Marxism since Lenin (New York: Basic Books, 1972). The subtitle makes clear our political intention.

${ }^{3}$ My translation from the note in the "Vorarbeiten" titled by its editors "Nodal Points in the Development of Philosophy” as published in Karl Marx. Frühe Schriften, H-J Lieber and Peter Furth, editors (Stuttgart: Cotta Verlag, 1962), p. 104.
} 
imperative, analyzing critically the present while opening a future horizon could not be fulfilled by a single academic discipline such as sociology or economics; critical analysis of the present coupled with a normative reflection on the positive possibilities latent within it has always been the domain of political philosophy. The domination of analytic philosophy in most major philosophy departments dismissed concern with history or politics as speculative. ${ }^{4}$ It was (barely) legitimate to appeal to the existentialist voluntarism of Jean-Paul Sartre; but his demonstration that Marxism is "the unsurpassable horizon of our times," elaborated in the 8 oo plus pages of his Critique of Dialectical Reason (1960) were translated only in 1976. It was more acceptable to turn to Husserl's phenomenological concept of the life-world (and lived-experience as a "horizon") in Husserl or Heidegger, although the latter had been discredited politically and only the first volume of Husserl's Ideas had been translated. However interested, most Americans did not have the linguistic competence to pursue this path.

Marxism in the adulterated forms of dialectical materialism was not a serious philosophical or political alternative. After the ravages of McCarthyism, there was no political market for it. I bought my first copies of Capital in the summer of 1965 from an old communist from San Antonio who would drive to the University of Texas in Austin with a trunk full of literature from Progress Publishers in Moscow. Party control of Marx was maintained also by the American affiliate, International Publishers, who interviewed me about translating the young Marx on Christmas Eve of 1970. When I suggested that there would of course be translator's explanatory notes, the meeting came to an end! The idea that an independent translator, whose ideology they didn't know in advance, would be given a free hand must have seemed extravagant to the faithful. ${ }^{5}$ One option remained; our New Left was not the first new left, nor had American always been a status quo society. This insight gave rise to the movement of "history from below" which was pursued in the pages of the

\footnotetext{
4John Rawls' Theory of Justice, published only in 1971, plays no role in the story I am telling. As for the British, the existence of a still vibrant trade union tradition helps to explain the persistence of a more-or-less orthodox Marxist orientation among leftists.

${ }^{5}$ Curiously, only a few years later, the mainstream editor Doubleday published in 1972 a 450 page compilation of The Essential Stalin: Major Theoretical Writings, 1905-1952, edited by Bruce Franklin. C.f. the ironic critical review by Paul Breines in Telos No. 15 (Spring 1973).
} 
journal Radical America. Although the initiative came from historians (led by Paul Buhle), the pages of this mimeographed journal were open to philosophical and critical theory as well. The young Marx found a place here, as did contemporary French theory, as did I. ${ }^{6}$

Of the politically engaged theoretical journals that flourished in the late 196os Telos was the most provocative. After two issues as the "official bi-yearly publication of the Graduate Philosophy Association" at Buffalo, the journal defined itself as "definitely outside the mainstream" in issues 3 to 5 (Spring 1969-Spring 1970); a year later, it was a more modest "international interdisciplinary quarterly," but its radical editors defined themselves in numbers 10 and 12 (winter 1971 and Summer 1972) as "revolutionary" rather than simply "radical." The labels are unimportant; crucial was the fact that the journal remained resolutely international. Its history was marked by disagreement, dissent and ruptures, each justified by appeal to the practical implications of theoretical choices. ${ }^{7}$ Intellectual, political and personal issues both bound together and separated the editors. Speaking for myself, I joined the editorial board with issue 6 (which contained among others, essays of Tran Duc Thao on the "Hegelian dialectic," Maurice Merleau-Ponty on "Western Marxism," Georg Lukacs on the "Dialectics of Labor" and Agnes Heller on "The Marxian Theory of Revolution." ${ }^{8}$ ). The is volume editors were on a voyage of initiation that began with two issues consecrated to the repressed works of Georg Lukács (numbers 10 and 11, 1971-2). Looking today at the old volumes, I'm a bit astonished by the breadth and depth of their themes. One finds here the

\footnotetext{
${ }^{6}$ C.f., "French New Working Class Theory" (Vol. III, No. 2, May 1969) and "Genetic Economics vs. Dialectical Materialism” (Vol. III, No. 4, August 1969). My edition of the Selected Political Writings of Rosa Luxemburg (New York, Monthly Review Press, 1971) was designated "A Radical America Book" whose small honoraria went to the journal, and with the hope that others young leftist intellectuals would follow my lead.

${ }^{7}$ Robert Zwarg has recently published a lucid, richly detailed and critically argued study of Die Kritische Theorie in Amerika. Das Nachleben einer Tradition (Göttingen: Vandenhoeck \& Ruprecht, 2017). Zwarg uses the development of Telos and New German Critique to trace the afterlife of the Frankfurt tradition of critical theory. In the course of his presentation, he also offers a generous account of Radical America.

${ }^{8}$ The 364 pages of this issue also included my "On Marx's Critical Theory" which used Marx's recently published "Results of the Immediate Production Process" to demonstrate a continuity between the social analysis of the young Marx and the work of the mature political economist. As Rosa Luxemburg (whose work I was editing at the time) intuited, capitalism and its contradictions can only be understood as a system of social reproduction.
} 
juxtaposition of an archeology of critical Marxism with a concern for French political debate (André Gorz and Serge Mallet, the Hegel revival facing the challenge of structuralism) as well as critical readings of attempts in East Europe to revive critical Marxism (e.g., the Budapest School, Prague philosopher Karel Kosik, T.W. Adorno and Ernst Bloch, the banned Yugoslav Praxis philosophers and the unrepentant Karl Korsch). The diversity of the contributions reflects the avid curiosity of the authors. For example, the translation of a brief obituary from the Frankfurter Rundschau of Adorno written by his rebellious student, Hans-Jürgen Krahl, is a sign of this avidity. But this eager openness and free floating critical spirit did not last.

I left Telos officially with issue 36 (Summer, 1978), after entering dissidence in 1974. During the first years of Telos, the Vietnam war continued, as did opposition to its senseless pursuit. The rapid selfinitiation into the varieties of Marxist theory and the nuances of its practice seemed all the more urgent; working with texts in French and German, providing translations and commentaries on them, the editors had remained "definitely outside the mainstream." But a problem arose from the identification of Marx's theory as the key to a revolution that seemed ever more pressing as the war continued and governmental repression at home increased. Repression had to be met with resistance, on all fronts, including that of theory. ${ }^{9}$ One expression of this dogmatism was that the editors were unwilling to publish the essays by Claude Lefort and Cornelius Castoriadis that I had proposed; their explicit critiques of Marx were too much to accept. The two French intellectuals had been dissident Trotskyists who created the political group and journal Socialisme ou Barbarie. Although their paths had diverged at points, they had both developed a critique of Marxism (and its relation to totalitarianism) that was little known at the time but became one of the dominant strands of antitotalitarian and democratic theory in the late

\footnotetext{
${ }^{9}$ I had a first experience of the problem of othodoxy at a conference in Italy on Rosa Luxemburg in 1973. I had asked how Rosa Luxemburg could be the most innovative of Marxist activists and yet the most dogmatic defender of Marx's texts (for example, against Bernstein's revisionism). As it happens, the following day saw the coup d'état in Chile against Allende. I instantly became persona non grata! A version of that paper is found in Telos, issue 18, "Rethinking Rosa Luxemburg." Another example of this kind of pressure is seen in Trent Schroyer's article on "The Dialectical Foundations of Critical Theory" (in issue 12). Already defensive, the author begins: "Despite the vilification of the left, and to the dismay of the academy, Jürgen Habermas remains a Marxist."
} 
1970s, and beyond. I prevailed ultimately, writing introductions to both of their work (in issues 22 and 23, Winter 74-Spring 75). But there was now a worm in the fruit; my concern was not to defend the faith in Marx but to recover the spirit of the New Left. By this time, the journal had become what I called a "meta" forum. It was publishing critiques or revisions of the unorthodox representatives of the "unknown dimension" whose aura had drawn the original editors to the project but who were no longer "definitively outside" the establishment. I managed to insure publication of some contributions, mainly on French themes, but the trains were on different tracks. In spite of the cosmopolitanism of its multi-lingual book reviews, and the diversity of its contributions (some resuscitating forgotten Marxian radicals like Karl Korsch (e.g., issue 26, Winter 1975), others joining theoretical analysis with contemporary politics (e.g., issue 16 containing Marcuse's 1930 essay on the concept of labor with André Gorz's analysis of the division of labor in the modern factory), the reheated dinner no longer satisfied my imagination. ${ }^{10}$

The motivation that had brought me to Telos led me to return to the journal as "Notes" editor with issue 58 (1983). The journal had begun to published original essays and translations from Eastern Europe where the challenge of Polish Solidarnosc trade union to the totalitarian state was relayed by oppositional intellectuals in Hungary and elsewhere. Telos benefitted from the presence in New York of two Hungarian students of Lukács, Agnes Heller and Ferenc Feher. There was excitement in the West as well, as the idea of the autonomy of civil society began to take hold. This seemed to confirm much of what Lefort and Castoriadis had asserted; and Telos had published essays by them both on the anniversary of the Hungarian revolution in issue 29 (Fall 1976). I took responsibility for the "Notes" section of the journal because the times did not seem right for a new grand theory; it was more pertinent to try to understand the novelty of the wholly unexpected movements first in the East and (hopefully) then in the West ${ }^{11}$.

\footnotetext{
${ }^{10}$ The last article that I published, "Enlightened Despotism and Democracy" (in issue 33, Fall 1977) built from an historical historical reconstruction to pose a question that led me to turn from the model of the French revolution to reconsider the history of the American revolution. .

${ }^{11}$ A far-reaching synthesis that I found convincing was published in 1992 by two editors whose contribution to Telos had been significant was important was published Jean L. Cohen and Andrew Arato, in Civil Society and Political Theory (Cambridge: MIT Press, 1992). Both Cohen and Arato, as
} 
As it happened, I soon found myself in among the modest minority of editors; the proponents of grand theory came increasingly to the fore. I left the journal once again with issue 71 , in 1987. I was not surprised to find that issue 72 was devoted to the work of Carl Schmitt; I should have seen it coming. Brilliant thinker that he was, Schmitt became the court jurist of the radical phase of the Nazi regime. Defining "the political" by distinguishing the "adversary" from the "enemy", Schmitt's theories were picked up by dissident and antimarxist leftists starting in the late 196os. My misperception came from the fact that I, along with Lefort and Castoriadis, distinguish between "the political" which defines the framework within which "politics" can take place and politics itself. Already in 1974 I had titled an article "A Politics in Search of the Political," and a decade later, in the context of the East European emergence of civil society, I wrote about "The Return of the Political," and in the same year I proposed "A Political Theory for Marxism." 12 My conception of the "political" differed radically from Schmit's conservative-decisionist variant, which came to dominate the journal. Telos has continued to publish, apparently remaining on the conservative-traditionalist path.

\section{The French Connection}

There was another option open to the would-be New Leftist in the 196os: France. A country where the Communist Party had won a quarter of the vote in the post-war years, France seemed to proof the cultural legitimacy of a variety of Marxist discourse. What is more, it was also the home of critics of Marx who considered themselves to be leftists, many of whom were philosophers. The most famous was the "existentialist," JeanPaul Sartre (whose gesture in refusing the Nobel Prize for Literature in 1964 because he would appear to be accepting "bourgeois" values pleased many a young iconoclast). ${ }^{13}$ An American had a further reason to chose

well as Heller and Feher, finally left Telos by the early 199os, when they were unable to overcoming the Schmittian grand theorists

${ }^{12}$ C.f., "A Politics in Search of the Political," Theory and Society, 1, 1974, pp. 271-306; "The Return of the Political," Thesis Eleven, Nr. 8, 1984, pp. 77-91; and “A Political Theory for Marxism," New Political Science, Nr. 13, Winter 1984, pp. 5-26.

${ }^{13} \mathrm{C} . \mathrm{f}$ his declaration of refusal, reprinted in http://www.nybooks.com/articles/1964/12/17/sartre-onthe-nobel-prize/ 
France: its revolutionary tradition appealed to equality, whereas the American tradition of 1776 stressed individual liberty. Indeed, the Civil Rights Movement was demanding protection above all for individual rights. That choice was not a tactical error; but it had to be understood as only the first stage toward revolutionary change.

France between 1966 and 1968 provided both an initiation to Marx and a critique of Marxism. At the Communist Party's annual Fête de l'Humanité, I was refused free entry although I was a comrade living on scholarship. At a demonstration against the Vietnam war, a speaker from the party demonstrated the justice of the anti-war cause while showing its place in a long historical chain; at the end of his discourse, as the public applauded, he joined them, suggesting that he was not expressing his opinion but spoke the truth of historical necessity. A similar conviction animated the Trotskyists. Those who attended their (smaller, semipublic) meetings had to sign-in under a pseudonym, increasing the thrill and sense of the exclusivity of participation. ${ }^{14}$ The theoretical justification of this practice was that the revolution could come at any time, and that without an organized and knowledgeable leadership to give direction to the working class could fail, or be stolen and deformed (as was said to have been the case in the Soviet Union). The point was well taken; theory was necessary. I moved into the dormitory at Nanterre where I spent a good part of the day reading Marx's Capital while watching a nasty yellow smoke rise from the tin shacks of the neighboring bidonville that housed the immigrant workers brought to France to remedy the post-war labor shortage..

These were lessons that could not be drawn from books. The principal challenge was to identify the working class that was assumed to be the agent of revolution. ${ }^{15}$ Had the capitalist economy brought into being a "new working class," as several theorists whom I came to identify with the New Left claimed. Among them were Serge Mallet, whose analysis of La nouvelle classe ouvrière appeared in 1963; André Gorz published

\footnotetext{
${ }^{14}$ I later used my pseudonym when I published an article on Czech student dissidents that relied on information that could have harmed friends there. C.f., "Czech-Mating Stalinism" in Commonweal, May 17, 1968. I refer below to my debt to the dissidents whom I knew in the 1960 .

${ }^{15} \mathrm{I}$ had read already in one of the few books on Marx that was widely available, $\mathrm{C}$. Wright Mills The Marxists (New York: Penguin Books, 1962), that the crucial problem for a contemporary Marxist would be to define what the "working class" could mean in contemporary societies.
} 
Stratégie ouvrière et néo-capitalism in 1964; and Daniel Mothé published Militant chez Renaut in $1965 .{ }^{16}$ Mallet had been a functionary of the Communist Party; after he left the party due to its inability to understand the new Gaullist regime, his research was funded in part by a grant from Jean-Paul Sartre. Gorz was a journalist at the weekly magazine, Le Nouvel Observateur, author of the existentialist analysis of alienation in Le traitre, and a member of the editorial committee of Sartre's journal, Les Temps Modernes. ${ }^{17}$ Mothé, whom I came to know at the journal Esprit, a lineworker at the Renaut plant at Billancourt and a member of the group Socialisme ou Barbarie, insisted on the capacity of workers to organize themselves without the need for a political party to show them the way. What they shared was a welcoming eye for the new. Needless to say, all three were eager participants in the "events" of May 1968.

I have followed the French usage in talking about May 1968 as "events." What crystallized in the "March $22^{\text {nd }}$ Movement" at Nanterre before spreading and spiraling across France (and abroad) had little to do with Marx. In retrospect, the losers on the left were what I call the Marxists: the Maoists, who insisted that real revolution could not be led by students; logically consistent, their followers ignored the campuses and went instead to the working class suburbs, where they found no echo; and the Communist Party (and its trade unions) who did their best to restrain the unexpected movement that they could not master. For my part, at Nanterre, I had the feeling during the pre-May meetings on campus that I was back at a New Left meeting in the United States. It was as if the overpoliticized students who had harangued one another about the need to support the "peasants and workers of X" rather than the "workers and peasants of X" were now speaking English ${ }^{18}$ The price I paid for this

\footnotetext{
${ }^{16}$ All three of these books were published by the Éditions du Seuil. I discuss the theories of Mallet and Gorz in The Unknown Dimension, op. cit.

${ }^{17}$ Gorz's idea of a "new left" differed from my own vague understanding; his was strongly influenced by the Italian trade union theorists of the time. When we became good friends, he once told me that he was the editor who had refused to publish my essay on the American New Left in Les Temps Modernes, even though it had been accepted by his colleague, Claude Lanzmann.

${ }^{18}$ The former, I came to learn, identified with Maoism, the latter with one of the two Trotskyist factions. At the time, neither my knowledge of French nor my understanding of Marxist scholastics were sufficient to grasp the distinction. I did write in early June an account of the May events which was sent by courier (the post office was closed) to the journal Viet Report. I do not know whether it arrived; and the friend who borrowed by carbon copy never returned it!
} 
comfort was paradoxical; I had come to France to find a theory that could make political sense of my New Left experience not to repeat it in a new language.

A first reflection after the experience of May '68 led me back to Marx. What was the relation between the philosophical explorations of the young Hegelian whose analysis of capitalism explored the diverse ramifications of alienation (as both Entfremdung and as Entäusserung) and the author of Capital whose three thick tomes demonstrating the internal contradictions and necessary breakdown of capitalism I had been studying in the dormitory at Nanterre? The ebbing of the spirit of May seemed to lend weight to the structuralist arguments of Louis Althusser, who drew a sharp line between Marx's "scientific" work and his youthful philosophical explorations. The simultaneous publication in 1965 of his Pour Marx and the two collaborative volumes of Lire le Capital seemed to offer a material foundation for the New Left experience that I had come to France to find. The political price to be paid, however, was not realized by most at the time. ${ }^{19}$ The all-encompassing denunciation of ideology in the name of "science" left no room for subjectivity characteristic of the new left or the May movement; the result eliminated the pole of negativity characteristic of the dialectic. I tried to avoid this dead end in my revised dissertation on The Development of the Marxian Dialectic ${ }^{20}$. The qualifier "Marxian" (rather than the substantive "Marxist") was meant to show that his turn to political economy was based on the dialectical elaboration of Marx's youthful philosophical insights.

Other questions raised by the experience of May '68 led me back to the existential Marxism of Sartre. At the "First International Telos Conference" in October 1970, I proposed an analysis of "Existentialism and Marxism." ${ }^{21}$ I was led to this theme by a slim volume titled Ces idées qui

\footnotetext{
${ }^{19}$ I was part of the overflow crowd at Althusser's lecture, "Lénine et la philosophie," at the Société Française de Philosophie on February 24. Althusser, who remained a party member, could appeal to the science of structures to criticize forms of "ideology" that didn't fit the prevailing party views.

${ }^{20}$ (Carbondale: Southern Illinois University Press, 1972).

${ }^{21}$ Published in Towards a New Marxism (St. Louis: Telos Press, 1973). This self-publication was no doubt a sign of Telos' self-confidence rather than of the impossibility of commercial publication. I would similarly publish my first work with small leftist publications "outside the mainstream."
} 
ont ébranlé la France. Nanterre Novembre 1967-juin 1968 22 The author uses categories developed in Sartre's Critique of Dialectical Reason to reconstruct the tumultuous emergence on one campus of a revolt that "shook the nation." The author concludes on a note of pessimistic optimism. Sartre had tried to explain the transformation of external or objective relations of passive "seriality" through a movement creating a "group-in-fusion" through which alienated passive participants become for a moment active members. But the fused group is by its very existential nature unstable; it has to seek means to conserve its unity. At this point, existential Marxism clashes with communist party Marxism. Sartre introduces first the idea of an "oath" by which the fused group binds itself; but their existential intentions clash with the hard reality of "scarcity," which Sartre also calls the "practico-inert." The oath must then be enforced, ultimately by Terror enforced by a leader who functions as an external "totalizing third" which sometimes recalls Stalin, at others the communist party. This troubling political implication of the attempt to join existentialism and Marxism may be one reason that Sartre never completed the promised second volume of the Critique.

\section{The German Path: From Phenomenology to Critical Theory}

Paul Piccone's presentation of "Phenomenological Marxism" followed my critique of the marriage of existentialism with Marxism in Contributions to a New Marxism. The chief editor was summarizing his vision of the path that Telos had followed. The radical Italian phenomenologist, Enzo Paci who built on Husserl's posthumously published Crisis of European Sciences and Transcendental Phenomenology ${ }^{23}$ had been a crucial early influence. The phenomenological critique of the pretension of scientific objectivity

\footnotetext{
${ }^{22}$ The volume was published under the pseudonym of Epistémon (Paris: Fayard, 1968). Its author was Didier Anzieu, a psychoanalyst and professor of psychology at Nanterre.

${ }^{23}$ The German edition was first published in 1936. The English translation by David Carr appeared in 1970. Telos published some fragments of Husserl's text without authorization (in Number 4, Fall 1969). Affirming its political principles, the editorial page insisted that "Since ideas should neither be sold nor bought, none of the included material is copyrighted and can be used for any purpose whatsoever by anyone. It did the same with chapters from Maurice Merleau-Ponty's as yet untranslated Adventures of the Dialectic in Numbers 6 and 7. The English translation by Joseph Bien appeared only in 1973.
} 
showed how it is both results from and reproduces the alienation from the life-world, making the human quest for meaningful experience impossible. It took only a short step to see that the implacable logic of capitalism is a manifestation of a similar alienation. This became clear when Telos published Herbert Marcuse's 1928 "Contributions to a Phenomenology of Historical Materialism" in the same issue with a translation of Husserl's account of "Universal Teleology." That same issue contained Piccone's analysis of "Lukács' History and Class Consciousness Half a Century Later.” In his eyes, the book had the potential to reclaim today its explosive potential despite its sad book's political fate in the preceding years. Although I was not yet involved, two brief "Notes" that dealt with events in which I had participated made me receptive to the journal. One affirmed Telos' outsider perspective through a biting report on the American Philosophical Association's winter meeting (at the Waldorf Astoria hotel!). Intellectually irrelevant, the big name figures had worked against a condemnation of the Vietnam war, while their jobseeking graduate students were consigned to a Kafkaesque maze on the $18^{\text {th }}$ floor. The other Note criticized an international phenomenological colloquium in Schwäbish Hall, West Germany, for insufficient emphasis on the importance of the life-world. The exception was the synthetic conclusion presented by Paul Ricoeur. ${ }^{24}$

The political difference of a phenomenological foundation for radical politics from Althusser's structuralist Marxism is striking. The French Marxist's was criticizing a bourgeois subjectivism that led to a philosophical idealism that separated theory from its practical implications. Structural logic, as Althusser thought he found it in Capital, was to demonstrate the material condition of possibility of radical change, overcoming the separation of theory and praxis. The difficulty is that structuralism (like dogmatic materialism) leaves no place for the intersubjectivity that constitutes meaning in the life-world. By contrast, the phenomenological insistence on the primacy of the life-world led to the recognition that lived experience is inseparably the foundation of the world of the subject and the condition of its possible objectification in

\footnotetext{
${ }^{24}$ I agreed. It was Ricoeur's support that brought me to Paris, in part on the basis of an exchange of letters in which I tried to show how I thought phenomenology could provide the basis for rethinking new left and antiwar politics. See Ricoeur's letters of May 15, 1965 and November 5, 1965, and my letter of Feburary 6, 1966, in DH Archive at Stony Brook University.
} 
positive science. Neither can exist or be understood apart from the other. Phenomenology avoids the either/or of materialism and idealism; its stress on the lived experience of the embodied individual permits it to overcome what Lukács called "reification" and the young Marx denounced as "alienation." While this reading of phenomenology can veer toward a Hegelian-Marxist theory, the ideas of a life-world and the lived-experience within it were in fact fundamental for the emerging New Left. ${ }^{25}$

The similar political reflexes among New Leftists did not obviate the differences in their cultural and historical background. The German New Left experience was at first affected by the fact that the Social Democratic Party had decided at its Bad Godesberg Conference in 1959 to abandon its self-understanding as a class based party of revolution. As a reformist catch-all "peoples' party" it no longer referred to Marxism as its guiding philosophy. When its youth organization, the Sozialistische Deutsche Studentenbund (SDS), began to radicalize in ways that resembled the experience of their American counterparts in the other $\mathrm{SDS}^{26}$, they of course were tempted to return to the Marxism and class theory that the reformist leaders rejected. As opposed to their American counterparts, they had access to the original German texts. ${ }^{27}$ This was a temptation that could be scholastic debates about text interpretation, or dogmatic claims to know better than the simple participants. In both cases, it turned attention away from the creativity of practical interventions that were rapidly changing the inherited mandarin culture.

The German New Left was certainly more bookish than most of its American cousins. They were also more concerned with the past. Not only did it have Marx; it had returned anti-fascist exiles who had resisted the blandishments of both totalitarianisms. In the case of the Frankfurt School, when Horkheimer and Adorno returned the no longer identified as critical theorists in the Marxian tradition. They refused to republish the

\footnotetext{
${ }^{25}$ I leave aside the very different interpretation of the life-world and lived-experience by Heidegger. It did not play a significant role among readers of Telos, although most did read the (difficult) translation into English and some were fascinated by its still influential French variant.

${ }^{26}$ Students for a Democratic Society had been the youth organization of the Social Democratic League for Industrial Democracy. It declared its autonomy in 1960.

${ }^{27}$ In fact, the generally available and inexpensive East German edition (the Marx Engels Werke, familiarly called "die blaue Bänder) did not include many of the early philosophical work of the young Marx. These could be found in the Frühe Schriften published by the Cotta Verlag in 1962.
} 
yearly volumes of the Zeitschrift für Sozialforschung published between 1932 and 1941. Horkheimer became an academic figure at the university, while Adorno was widely known for his cultural-critical interventions on the radio. But their reputations had preceded them. The radical students began to publish pirate editions, photocopies of the original texts, glued together on cheap paper, usually with red cover pages, as a sort of Samizdat! Among those that I purchased at the Karl Marx Buchhandlung in Frankfurt between 1968 and 1970 are the complete edition of the Zeitschrift, and three volumes of Horkheimer's essays titled Kritische Theorie der Gesellschaft, as well as the Dialektik der Aufklärung and Authorität und Familie. Two other small volumes by Horkheimer also remain on my shelves: the Anfänge der bürgerlichen Geschichtsphilosophie and three essays from his most radical period, 1939-41, published under the title, Autoritärer Staat ${ }^{28}$

Whether their books concerned Marx or the Frankfurt School, the German New Left was a generation of readers. So were all of the New Lefts. One cultural trait whose roots can be seen already in the romanticism of the $19^{\text {th }}$ century that marked the Germans political understanding was that the idea of a life-world that must be protected against instrumentalization, rationalization or mechanization. The refusal to treat what should be an end in itself as a means to something else, be it capitalist domination or a science acquired at the cost of one's humanity, is a tradition that goes back to the German Enlightenment and to Kant. At their most pessimistic, Adorno and Horkheimer constructed an historicalontological "dialectic of enlightenment" that arises when reason turns on itself and unreason comes to dominate, as it had after 1933. Horkheimer had written a somewhat less fatalistic interpretation, more political version in The Eclipse of Reason (1947). Significantly, its German edition twenty years later, as Zur kritik der instrumentellen Vernunft, was more

\footnotetext{
${ }^{28}$ Perhaps in the Enlightenment tradition when Amsterdam was a center of pirate editions, the lastnamed book had a publisher ((Amsterdam: Verlag de Munter, 1967), the others were usually done by anonymous collectives. There were other pirate editions, for example of Karl Korsch and of Wilhelm Reich's 1934 journal called Sex-Pol (as well as a pocket-sized, illustrated version of Der sexuelle Kampf der Jugend). There were also editions of authors who had abandoned their former political theories, such as Karl August Wittfogel, Franz Borkenau, and Richard Löwenthal under the pseudonym Paul Sering. Another large volume retyped previously published texts from academic journals under the title Kritik und Interpretation der Kritischen Theorie: über Adorno, Horkheimer, Marcuse, Benjamin, Habermas.
} 
than twice its size. Its final essay, which dates from 1965, reaffirms the goals of critical theory-the critique of the existing order-with the caveat that the "threats to freedom" that are the subject of his text have changed.

The new German radicals wanted not only to criticize the existing world; they wanted to change it. Seeking their way, they tried to return to the origins of critical theory. They read Horkheimer's path breaking essay "Traditional and Critical Theory" and-having read Marcuse's OneDimensional Man-they eagerly read the exchange between Horkheimer and Marcuse titled "Philosophy and Critical Theory." ${ }^{29}$ Then they went back still further, to Marx, especially the young Marx. What they found give a deeper sense to critical theory.

Those who did the reading had to be struck in particular by two passages. The first, in "Exchange of Letters" that introduced the DeutschFranzösischen Jahrbücher, insists: that "We do not face the world in doctrinaire fashion, declaring 'Here is the truth, kneel here!'...We do not tell the world, 'Cease your struggles, they are stupid; we want to give you the true watchword of the struggle.' We merely show the world why it actually struggles; and consciousness is something that the world must acquire even if it does not want to." This is a straightforward formulation of the idea of immanent critique. It did not, however, suffice on its own. Marx went on to apply this critical theory in his "Introduction to a Critique of Hegel's Philosophy of Right. " "Man, he begins, "is not an abstract essence existing outside the world. Man is the world of men, state, society." The task of the immanent critique is "to make these reified relations dance by singing to them their own melody." As the analysis becomes more concrete, step by immanent step, the "man" from whom Marx began becomes the "proletariat." In this incarnation, the "world of men" is an object that is produced by a certain type of self-reflective society; yet it remains always a subject capable of praxis and understanding-of making a revolution!

The problem for the New Left was that the proletariat conceptualized by Marx no longer existed; what some have called the "Victorian capitalism" that Marx knew exists no longer. A "new working class" had come into being. I traced some early analyses of its emergence

\footnotetext{
${ }^{29}$ All three essays appeared in volume 6 of the Zeitschrift für Sozialforschung (1937), which was copyrighted in Paris by the Librairie Félix Alcan in 1938.
} 
by André Gorz and Serge Mallet in the last chapter of The Unknown Dimension, and returned to it in a recent essay on "La philosophie charnelle d'André Gorz". ${ }^{30}$ That seemed to leave two options for a revolutionary vision of immanent critique. The first would pursue the project on the terrain of culture that had been staked out by Adorno and the increasingly popular Walter Benjamin. Elements of this option have been described recently by Philipp Felsch's study, Der lange Sommer der Theorie. Geschichte diner Revolte, 1960-199o, which reconstructs the integration of French deconstruction theory into Germany by the Merve Verlag. ${ }^{31}$ Most of the story that Felsch recounts takes place outside of the framework of the present account. However one factoid that he cites at the outset points toward the second option for a radical left.

At the time of his death in prison, the founder of the (terrorist) Red Brigades, Andreas Baader, had become an voracious consumer of the works of Marx, Marcuse, and Reich; nearly 400 volumes were found in his cell. Baader represented an extreme version of the other option for the New Left: an actionism, which claimed to be a praxis that did in its way what Marx had advocated for critical theory. Although the activists have thought they could "make the reified relations dance by singing before them their own melody," the song that they sung their opposed own violence to that of an unjust society. It is true 1968 was a year that had seen the French May events, followed by the police violence at the democratic party convention in Chicago, the pursuit of the war in Vietnam and the crushing of Prague spring by Soviet and allied tanks. The praxis faction argued that by provoking state-violence their actions forced the ruling class to reveal the iron fist within the velvet glove. This superficial and antipolitical option was denounced as "left wing fascism" by the heir to the Frankfurt School, Jürgen Habermas, at an assembly of 2000 activists on June 2, 1968. Although he later admitted that this was a bad choice of words, Habermas point was telling. ${ }^{32}$

\footnotetext{
$3^{\circ}$ Published in Esprit, janvier 1914; English translation as "André Gorz and the Philosophical Foundation of the Political," in Dick Howard, Between Politics and Antipolitics, thinking about Politics after 9/11 (Palgrave Macmillan 2016).

${ }^{31}$ München: Verlag C.H. Beck, 2015).

${ }^{32}$ I discuss Habermas's strictly political writings in chapter 8 of Between Politics and Antipolitics. Thinking about Politics after 9/11 (New York \& London: Palgrave Macmillan, 2016). I knew some of $\mathrm{f}$
} 
With the turn to violence what I called the New Left's age of innocence came to an end. The search for an "unknown dimension" continued, although Marx was no longer considered to be its origin. In France in the mid-1970s, as if to atone for past orthodoxies, antitotalitarianism became an inspiration for former New Leftists. In Eastern Europe, antitotalitarianism became a practical reality; in 1989 the Berlin Wall came down, and in 1991 the Soviet Union disappeared. As the case in Telos illustrates, it seemed to many, that a new New Left could take shape around the concept of "civil society" This was a familiar concept for the heirs to the earlier New Left who had read the young Marx. Those who adopted did not pay sufficient attention to the origin of the concept with Hegel, who saw civil society as only a particular mediation between the immediacy of family life, and the universality of the political state. An autonomous civil society cannot stand alone. The political renewal of the mediations that Hegel called the family and the state stands today as the "unknown dimension" that could animate a new New Left. Marx may well continue to offer us his help in our contemporary search for what he had called a "new continent."

\section{References}

Cohen, Jean L. and Andrew Arato. Civil Society and Political Theory. Cambridge, Mass.: MIT Press, 1992.

Epistémon (Didier Anzieu). Ces idées qui ont ébranlé la France. Nanterre Novembre 1967juin 1968. Paris: Fayard, 1968.

Felsch, Philipp. Der lange Sommer der Theorie. Geschichte diner Revolte, 196o-199o. München: Verlag C.H. Beck, 2015.

Franklin, Bruce, editor. The Essential Stalin: Major Theoretical Writings, 1905-1952. New York: Anchor Books 1972.

Howard, Dick, editor. Selected Political Writings of Rosa Luxemburg. New York, Monthly Review Press, 1971. 
Howard, Dick. The Development of the Marxian Dialectic. Carbondale: Southern Illinois University Press, 1972.

Howard, Dick. Towards a New Marxism. St. Louis: Telos Press, 1973.

Howard, Dick. The Specter of Democracy. New York: Columbia University Press, 2002. Paperback edition, 2006.

Howard, Dick. Between Politics and Antipolitics, thinking about Politics after 9/11. New York \& London: Palgrave Macmillan 2016.

Klare, Karl E. and Dick Howard. The Unknown Dimension. European Marxism since Lenin. New York: Basic Books, 1972.

Marx, Karl. Frühe Schriften, H-J Lieber and Peter Furth, editors. Stuttgart: Cotta Verlag, 1962

Mills, C. Wright. The Marxists. New York: Penguin Books, 1962.

Rawls, John. A Theory of Justice. Cambridge, Mass.: Harvard University Press, 1971.

Zwarg, Robert. Die Kritische Theorie in Amerika. Das Nachleben einer Tradition. Göttingen: Vandenhoeck \& Ruprecht, 2017.

\section{Endereço postal}

State University of New York

10 West $15^{\text {th }} \# 1725$

New York, NY 10011

Data de recebimento: 11/01/2018

Data de aceite: 11/03/2018 